九州大学学術情報リポジトリ

Kyushu University Institutional Repository

\title{
Biological Safety Assessment of Functional Activated Carbons Prepared from Three Agricultural Wastes
}

Lin, Han Chien

Laboratory of Environment Functional Materials, Department of Wood Based Materials and Design, College of Agriculture, National Chiayi University

Tseng, Li-Ying

Graduate Institute of Forest Products Science, College of Agriculture, National Chiayi University : Master

Lai, Ying-Jang

Department of Food Science, College of Science and Engineering, National Quemoy University

Wu, She-Ching

Department of Food Science, College of Life Science, National Chiayi University, 他

https://doi.org/10.5109/1467641

出版情報：九州大学大学院農学研究院紀要. 59 (2)，pp.321-331，2014-08-29. Faculty of Agriculture, Kyushu University

バージョン :

権利関係 : 


\title{
Biological Safety Assessment of Functional Activated Carbons Prepared from Three Agricultural Wastes
}

\author{
Han Chien LIN ${ }^{1 *}$, Li-Ying TSENG ${ }^{2}$, Ying-Jang LAI ${ }^{3}$, \\ She-Ching $\mathrm{WU}^{4}$ and Noboru FUJIMOTO ${ }^{5}$
}

\author{
Laboratory of Wood Material Technology, Division of Sustainable Bioresources Science, \\ Department of Agro-environmental Sciences, Faculty of Agriculture, \\ Kyushu University, Fukuoka 812-8581, Japan \\ (Received March 8, 2014 and accepted May 12, 2014)
}

\begin{abstract}
This study prepared agricultural waste corn cob, bagasse pith and mushroom stalk activated carbons at different activation temperatures, and selected the activated carbon (AC) with better yield and iodine value for cytotoxicity and mutagenicity tests as well as biological safety assessment. The selected AC in regard to toxicity, the amount of residual bacteria was larger than that of the control group by more than $80 \%$, meaning no cytotoxicity. The Salmonella typhimurium TA98 and TA100 of the AC did not exceed spontaneous revertants by more than two times, determining no mutagenicity. The feeding specimen for acute and subacute toxicity tests was $850^{\circ} \mathrm{C}$ corn cob AC. The observed weight, feed/water consumptions, feed conversion rate and urinalysis, organ weight, tissue slice as well as blood analysis in the results exhibited no significant difference to the Sprague-Dawley rat (SD rat) of the control group. The blood serum biochemical analysis result showed that the blood sugar of female rats of the control group and test group apparently decreased, but the blood urea nitrogen, aspartate aminotransferase and phosphorus of the test groups were higher than the normal range of SD rat of the National Laboratory Animal Center, and were not significantly different from the control group. According to the aforesaid results, the corn cob $\mathrm{AC}$ prepared at $850^{\circ} \mathrm{C}$ is in the test dose range of biological safety assessment, and is undoubtedly safe.
\end{abstract}

Key words: Activated Carbon (AC), Agricultural Wastes, Biological Safety Assessment, Mutagenicity

\section{INTRODUCTION}

The annual output of agricultural wastes in Taiwan is more than 5 million MT (Council of Agriculture Annual Report, 2011), including seven major categories: cereal waste, special crop waste, vegetable and fruit waste, food factory waste, mushroom culture medium waste, livestock and cultivation waste, as well as garden and street tree (Yang, 1992). The corn cob is classified as cereal waste; its annual output is about 200,000 MT (Yang et al., 2003). It contains $41 \%$ cellulose, $36 \%$ hemicellulose, $3 \%$ cutin and $0.6 \%$ lignin ( $\mathrm{Lu}, 1993)$, and is used mainly as fuel, compost cultivation medium and for seedling-raising. The bagasse pith belongs to special crop waste. The Council of Agriculture (COA) Annual Report indicated that the production of sugarcane was 548,455 MT in 2011. The production of bagasse pith is $23 \%$ of cane stalk, about

Laboratory of Environment Functional Materials, Department of Wood Based Materials and Design, College of Agriculture, National Chiayi University, Chiayi, Taiwan, ROC.

${ }^{2}$ Master, Graduate Institute of Forest Products Science, College of Agriculture, National Chiayi University, Chiayi, Taiwan, ROC.

Department of Food Science, College of Science and Engineering, National Quemoy University, Quemoy, Taiwan ROC.

${ }^{4}$ Department of Food Science, College of Life Science, National Chiayi University, Chiayi, Taiwan ROC.

Laboratory of Wood Material Technology, Division of Sustainable Bioresources Science, Department of Agroenvironmental Sciences, Faculty of Agriculture, Kyushu University, Faculty of Agriculture, Kyushu University, Japan.

* Corresponding author (E-mail: alexhlin@mail.ncyu.edu.tw)
126,145 MT. Its principal constituents include 20\% lignin, $46 \%$ cellulose, $24.5 \%$ hemicellulose, $2.4 \%$ ash and $2 \%$ crude protein (Yang et al., 2003); at present, 60\% is used as fuel for the boilers of sugar mills (Chou, 1998). In addition, according to 2008 COA Annual Report, the mushroom production of Taiwan is 4,233 MT, including 3,887 MT of space bag mushroom and 346 MT of wood-based mushroom. The weight of the stalk is $50 \%$ of an entire mushroom, its annual production is about 1,945 MT. Its principal constituents include $20.3 \%$ crude protein, $3.4 \%$ crude fat, $8.9 \%$ coarse fiber, $52.9 \%$ nitrogen free extract and $4.2 \%$ ash (Tung et al., 1961). It is mostly used as raw material in food processing.

The activated carbon (AC) is a type of porous carbonaceous matter (Hsieh, 1998). At present, the common raw materials (precursor) for preparing $\mathrm{AC}$ are fibrous materials, such as coconut shell, peanut shell, rice hull, hardcore, coffee bean, bagasse, and cotton seed hull. Commercial AC is mostly wood, coconut shell and coal (Wigmans, 1989). The AC has a very special pore structure, usually represented by pore volume and pore size (Lu, 1994). Based on the distribution of pores in different diameters, pore structure and high specific surface area, the specific surface area of AC is usually 500 to $1,500 \mathrm{~m}^{2} / \mathrm{g}$ (Huang, 2002). It is more applicable to adsorbing organic pollutants for its high specific surface area (Wu and Tseng, 2000). The precursor for preparing an AC is high carbon material. Most agricultural wastes contain high content of cellulose; if the agricultural wastes can be prepared into AC efficiently, the value of waste is increased. On the other hand, the "Resource Recovery Four-inOne Program" and the policy of "Full Waste Classification 
and Zero Waste Group Action Plan" promoted by the Environmental Protection Administration (EPA) in Taiwan would be fulfilled.

The three agricultural wastes may be made into functional AC, for example, for diet (e.g. placed in salt, pepper or flavoring jars to keep them dry and prevent deliquescence and foreign flavor; the $\mathrm{AC}$ can be mixed with various foods; it can remove in vivo toxins with defecation) or as treatment process (e.g. purifying drinking or medical water, indoor and outdoor or in-car aromatics; conserving medical drugs), the feasibility of AC as functional environmentally friendly material is studied herein. The prepared AC according to Item 2, Article 3 of Health Food Control Act and the health food safety assessment method specified in W.S.S.Z. No. 88037803 announcement of Ministry of Health and Welfare (1999) in Taiwan, referring to the "Good Laboratory Practice for Nonclinical Laboratory Studies" announced by the Ministry of Health and Welfare on June 29, 1998, was investigated. However, the Ames test should be carried out before the biological safety assessment (Ames, 1975); when it is confirmed without mutagenicity, and applied to mammalian in vivo testing. The mammalian test contains an acute toxicity test and subacute toxicity test. The preliminary experiment on mammals is conducted before the acute toxicity test and subacute toxicity test, to avoid inappropriate dosage resulting in unnecessary sacrifices. The feeding dose for acute and subacute toxicity tests was 5-10 times the maximum dose level for subacute toxicity test $(1 \mathrm{~g} / \mathrm{kg} /$ day) specified by the Ministry of Health and Welfare (Ministry of Health and Welfare, 1998); meanwhile, the maximum dose level of $\mathrm{AC}$ as antidote $(1 \mathrm{~g} / \mathrm{kg})$ in the prevention and response manual (Emergency Response Information Center, 2006) written by the Emergency Response Information Center was referred to, and this test was carried out referring to the dose.

To sum up, this study used three agricultural wastes to prepare AC, and assessed its characteristics and safety for organisms. The prepared AC with better porosity and adsorptivity was used for cytotoxicity and mutagenicity, as well as rodent safety tests. The purpose was to evaluate the safety of agricultural waste AC for organisms, in order to discuss the feasibility of adding it in various foods as diet, or using it as functional environmentally friendly material in the treatment processes.

\section{MATERIALS AND METHODS}

\section{Specimen preparations and characteristics \\ Precursor}

Corn cob: sweet corn (Z. mays L.var.rugosa Bonaf) was bought from a farmer in the market. The cob was prepared and cut to about $3 \times 3 \times 2.5 \mathrm{~cm}$. Mushroom stalk: Lentinus edodes (Berk) stalk, in size of about $1 \times 1 \times 3 \mathrm{~cm}$, provided by Zhushan Pu Yuan Art Studio. Bagasse pith: the squeezed sugarcane (Saccharum officinarum) bagasse was used, bought from a specific farmer in the market; the size was about $1.5 \times 0.5 \times 2 \mathrm{~cm}$. Three precursors were dried in oven at $105^{\circ} \mathrm{C}$ for future use.

\section{Salmonella typhimurium (S. typhimurium)}

The test strains were included TA98 and TA100, bought from Bioresource Collection and Research Center, Food Industry Research and Development Institute in Taiwan.

Rat liver mixture (S9)

Some substances lack toxicity in nature, but when they are activated by the enzymes in a human or animal body, and carcinogenic substances are formed. Some toxicants are metabolized to derivants without carcinogenicity. These are drug-metabolizing enzymes active in detoxifying extraneous materials in vivo. Various tissues of animals have these enzymes, and the highest content is in the liver. S9 is the rat liver cell extract; this enzyme is added to simulate the intravital metabolism of organisms.

Sprague-Dawley rat (SD rat)

They were bought from National Laboratory Animal Center, incorporated foundation National Applied Research Laboratories in Taiwan, there were 20 4-5 week old male and female SD rat for acute animal testing, and there were 40 4-5 week old male and female SD rat for subacute animal testing.

\section{Measurement of basic properties of precursor}

Water content: the prepared precursor was taken at random, placed in an oven at $105^{\circ} \mathrm{C}$, dried to constant weight, and the water content was calculated. Specific gravity: the precursor was taken at random, placed in an oven at $105^{\circ} \mathrm{C}$, dried to constant weight, and the absolute dry volume was measured to calculate the specific gravity. Ash content: the ash content is measured in accordance with CNS 67176. The weight of content was measured repeatedly till the error was less than $0.1 \mathrm{mg}$.

\section{Preparation and iodine value of $\mathrm{AC}$}

The corn cob, mushroom stalk and bagasse pith were put in the closed container of super-high temperature vacuum carbonization activation equipment (Chi-How Heating Co., Ltd.). One dose was about $40 \mathrm{~g}$. The nitrogen was added in at Stage I to make the container oxygen free. The heating rate was $10^{\circ} \mathrm{C} / \mathrm{min}$, and the carbonization temperature was $700,750,800,850,900$ and $950^{\circ} \mathrm{C}$. The activation of Stage II began when the desired temperature was reached. The temperature was 700,750 , $800,850,900$ and $950^{\circ} \mathrm{C}$. The imported gas was carbon dioxide, and the activation time was $90 \mathrm{~min}$. At Stage III, the materials were cooled by nitrogen to normal temperature and taken out. The aforesaid preparation conditions refer to (Chang et al., 2001; Juang et al., 2002). The equation for $\mathrm{AC}$ yield $(\mathrm{Y})$ is $\mathrm{Y}(\%)$ = bone dry weight of AC/absolute dry weight of test material $\times 100$.

The iodine value is tested as per JIS K 1474 (1991). The AC particle size was 40 to 60 mesh. The equation of iodine adsorption quantity is $\mathrm{I}=(10-\mathrm{K} \times \mathrm{f}) \times 12.69 \times 5 / \mathrm{M}$; (I: iodine adsorption quantity (mg/g); K: volume of sodium thiosulfate solution for titration (ml); f: ratio of $0.1 \mathrm{~N}$ sodium thiosulfate solution to $\mathrm{O} .1 \mathrm{~N}$ iodine solution; $\mathrm{M}$ : absolute dry weight of sample). 


\section{Ames test}

Cytotoxicity

$1,2.5,5.0,7.5$ and $10.0 \mathrm{mg}$ corn cob (activation temperature $\left.850^{\circ} \mathrm{C}\right)$, bagasse pith $\mathrm{AC}\left(850^{\circ} \mathrm{C}\right)$ and mushroom stalk $\mathrm{AC}\left(800^{\circ} \mathrm{C}\right)$ were put in the test tube, mixed with $0.7 \mathrm{~mL}$ phosphate buffer saline and $0.1 \mathrm{~mL}$ S. typhimurium TA98 and TA100, and cultured overnight in nutrient broth. If there was additional S9, the aforesaid addition level was changed to $0.2 \mathrm{~mL}$ phosphate buffer saline, $0.1 \mathrm{~mL}$ S. typhimurium TA98 and TA100, and cultured overnight in nutrient broth and $0.5 \mathrm{~mL}$ S9 or zero $\mathrm{S} 9$. Afterwards, the test tube was pre-cultured at $37^{\circ} \mathrm{C}$ for $20 \mathrm{~min}$, the dilute mixed liquor was taken out, and then $1 \mathrm{~mL}$ diluent was put in the plate, mixed with nutrient agar and shaken up. When the mixture solidified, the plate was placed in the incubator at $37^{\circ} \mathrm{C}$ for $48 \mathrm{~h}$. The colony count was calculated; if the bacterial count of test group (with $0.5 \mathrm{~mL} \mathrm{S9}$ or without S9) is larger than the bacterial count of control group by $80 \%$, there is no toxicity (Ames, 1975).

\section{Mutagenicity}

The mutagenicity is analyzed by using the method proposed by Maron and Amest (1983), and the dose range is selected according to the maximum dose level $(5 \mathrm{mg} /$ plate) specified by the Ministry of Health and Welfare (1999). The test dose selected for this mutagenicity test ( \pm S9) was $1-10.0 \mathrm{mg} /$ plate. $1,2.5,5.0,7.5$ and $10.0 \mathrm{mg}$ corn cob, bagasse pith and mushroom stalk AC and 0.1 $\mathrm{mL}$ phosphate buffer and $0.1 \mathrm{~mL} S$. typhimurium TA98 and TA100 cultured overnight in nutrient broth were put in the test tube, mixed with $0.6 \mathrm{~mL}$ phosphate buffer saline, and cultured at $37^{\circ} \mathrm{C}$ for $20 \mathrm{~min}$. Afterwards, the mixture was mixed with $2 \mathrm{~mL} 45^{\circ} \mathrm{C}$ Molten Top Agar (including $0.05 \mathrm{mM} \mathrm{L}$-histidine, $0.05 \mathrm{Mm}$ Biotin and $0.09 \mathrm{M} \mathrm{NaCl}$ ) uniformly; the Nutrient Agar was poured into the plate. When the mixture solidified, the plate was put in the incubator at $37^{\circ} \mathrm{C}$ for $48 \mathrm{~h}$, and then the colony count was calculated. In addition, the phosphate buffer saline only was a pair of blank groups (Control). If the colony count of the TA98 and TA100 test group is larger than the control group by more than two times, the specimen has mutagenicity (Maron and Amest, 1983).

\section{Biological safety assessment}

\section{Feeding and management}

According to general experimental animal feeding and management, the ambient temperature of feeding is $23 \pm 2^{\circ} \mathrm{C}$, the relative humidity is $40-60 \%$, lighting and darkness last $12 \mathrm{~h}$ each, and adequate feedstuff and water are provided. The animals were raised in Macrolon Cages with stainless steel cover. The bedding was Northern White Maple (Bedding Company). The feedstuff was Fwusow brand. The animals were raised for 5-7 days before test. The test material was given at a fixed time every day during the test period. The dose depended on the weight. The feed was delivered via stomach tube from the mouth.

Acute animal test

There were a control group and a test group; each group had 20 SD rat, male and female were half and half. The test group takes the maximum feeding dose $(5 \mathrm{~g} / \mathrm{kg})$ of the preliminary test as its dose, and the control group was fed with only physiological saline solution. The result is the dose reference for subacute toxicity test.

Subacute animal test

The SD rat was divided into four groups at random. Each group had 20 rats, male and female were half and half; there were 80 rats in all. The dose was 5-10 times of maximum dose level ( $1 \mathrm{~g} / \mathrm{kg} /$ day) for the subacute toxicity test as specified by the Ministry of Health and Welfare in Taiwan. According to the results of the preliminary test and acute animal test, the maximum dose level for this test was $5 \mathrm{~g} / \mathrm{kg} /$ day. The four groups were physiological saline solution (control group), low dose group ( $0.5 \mathrm{~g} / \mathrm{kg} /$ day), moderate dose group ( $1 \mathrm{~g} / \mathrm{kg} /$ day) and high dose group ( $5 \mathrm{~g} / \mathrm{kg} /$ day). The corn cob AC was fed through feeding tube for 28 days. When the test period ends, the feeding was stopped for 24 hours on the $27^{\text {th }}$ Day, then the rats were stupefied with ether, and the blood was taken from the vena portae hepatica for clinical pathology analysis.

Feed conversion rate

The dose was given according to the weight of the tested animal; the weight, food and water consumption were recorded at least once per week to calculate the feed conversion rate.

Organ observation and weighing

All the organs of the experimental animal were weighed, and their relative weight to the body weight was calculated; equation: relative weight percentage of organs $(\%)=$ organ weight $(\mathrm{g}) /$ body weight $(\mathrm{g}) \times 100$; then the tissues were made into specimens and covered, and the pathological tissues were observed.

Urinalysis

The chemical examination of urine used Japanese AMES ten-item urine test paper. The items include: urine color, specific gravity (Sp.Gr.), hydrogen ion concentration $(\mathrm{pH})$, occult blood (O.B), nitrite, ketones, glucose and so on.

\section{Blood examination}

The blood was collected in the anticoagulant test tube containing heparin (Lithium Heparin Plasma tube, Becton, Dickinson and Company, NJ, USA); the white blood cell (WBC) count, red blood cell (RBC) count, hemoglobin (HGB) and hematocrit (HCT) were measured by full automatic hemocytometer (SYSMEX K1000).

Blood serum biochemical analysis

The blood was collected in the test tube without anticoagulant; when the blood was agglutinated, the blood serum was separated centrifugally, the alanine aminotransferase (ALT) and aspartate aminotransferase (AST) were measured by blood serum biochemical autoanalyzer (CIBA-CORNING).

\section{Statistical analysis}

The test results of the feed conversion rate of SD rats, relative weight of organs, blood serum analysis, urinalysis, and blood analysis were represented by average values (standard deviation). The control group and test 
group are compared by Duncan's analysis. If the $\rho$ value is smaller than 0.05 , meaning significant difference between test group and control group, it is represented by different letters.

\section{RESULTS AND DISCUSSION}

\section{Basic properties of precursor}

In terms of basic properties of the precursors, the range of water content was 10 to $11 \%$. The mushroom stalk had the maximum specific gravity of 0.34 , and the bagasse pith had the minimum, 0.13 . The ash content of three precursors was 2.4 to $3.2 \%$, the mushroom stalk had the maximum ash content, and the corn cob had the minimum content. Generally, higher ash content in AC represents worse purity, such as the ash content in temperate tree species is lower than $0.5 \%$; in partial tropical tree species it is 1 to 4\% (Wang and Ting, 1984). In terms of principal constituents of three precursors, according to some studies, the principal constituents of corn cob include $41 \%$ cellulose, 36\% hemicellulose and 0.6\% lignin (Lu, 1993); the sugarcane bagasse contains 20\% lignin, $46 \%$ cellulose and $24.5 \%$ hemicellulose (Hsia, 1972); and the mushroom stalk contains $52.9 \%$ nitrogen free extract and $20.3 \%$ crude protein (Tung et al., 1961).

\section{Yield and iodine value of AC}

The yield and iodine value of AC at different temperatures are shown in Table 1. The yield of corn cob was 11.9 to $26.6 \%$; that of bagasse pith was 1.7 to $28.4 \%$; and that of mushroom stalk was 7.5 to $23.9 \%$. The yield decreases as the activation temperature increases because of the increase of the volatile matter, tar dissipation and gasification of carbon in raw material (Teng and Hus, 1999). The AC yield is also related to the carbonization temperature at Stage I of AC preparation; the yield decreases as the carbonization temperature increases (Abe et al., 1996). The yield of three precursors was at its maximum at activation temperature of $700^{\circ} \mathrm{C}$. The yield decreased as the activation temperature increased. This is related to the gasification capacity of carbon and the gasification capacity increases with the activation temperature (Chang et al., 1998 and 2003; Tseng et al., 2007; Wu et al., 2010; Huang et al., 2010; Peng et al., 2010).

The iodine values in the same table indicated that the corn cob AC had the maximum iodine value of $891 \mathrm{mg} / \mathrm{g}$ at $850^{\circ} \mathrm{C}$ in the range of 700 to $950^{\circ} \mathrm{C}$; the bagasse pith $\mathrm{AC}$ prepared at $850^{\circ} \mathrm{C}$ had the maximum iodine value of $1020 \mathrm{mg} / \mathrm{g}$; the mushroom stalk AC prepared at $800^{\circ} \mathrm{C}$ had the maximum iodine value of $685 \mathrm{mg} / \mathrm{g}$. The iodine value of general commercial AC is 600 to $1000 \mathrm{mg} / \mathrm{g}$ (Wu and Tseng, 1999), and the diameter of iodine molecules is $0.56 \mathrm{~nm}$; the iodine adsorption capacity of $\mathrm{AC}$ can be regarded as the capability of adsorbing nonpolar small molecules (Hsieh and Teng, 1999); it is the index of adsorbing micropores of AC. The physical activation has pore-drilling and expansion effects at $800^{\circ} \mathrm{C}$, producing multiple micropores (Lua and Guo, 2000; Yun et al., 2001). However, when the activation temperature is increased to $900^{\circ} \mathrm{C}$, the $\mathrm{CO}_{2}$ reacts excessively, so that the expansion effect is greater than the pore-drilling effect into the precursors, and the mesopores and macropores are the majority in the AC (Chen, 2003). The iodine value of corn cob AC at activation temperature of 700 to $850^{\circ} \mathrm{C}$ was 891,592 and $402 \mathrm{mg} / \mathrm{g}$. As the activation temperature increased, the pore-drilling effect and expansion effectoccurred simultaneously. The iodine value was 891, 796 and $664 \mathrm{mg} / \mathrm{g}$, when the activation temperature was 850 to $950^{\circ} \mathrm{C}$. Therefore, the physical activation has pore-drilling and expansion effects at $800^{\circ} \mathrm{C}$, producing multiple micropores (Lua and Guo, 2000; Yun et al., 2001). Moreover, when the activation temperature increases, as the expansion effect is greater than pore-drilling effect, the multiple mesopores or macropores are produced (Walker and Almagro, 1995; Hung-Pin Chen, 2003), so that the iodine value decreases. There was no apparent difference in the iodine value of bagasse pith $\mathrm{AC}$ at activation temperatures of 750 and $800^{\circ} \mathrm{C}$. The iodine value is 1020,943 and $871 \mathrm{mg} / \mathrm{g}$, when the temperature was 850 to $950^{\circ} \mathrm{C}$. The iodine value decreased as the activation temperature increased due to the expansion effect. The mushroom stalk AC had maximum iodine value at activation temperature of

Table 1. Yield and Iodine value of corn cob, bagasse pith and mushroom stalk activated carbons at different activated temperature

\begin{tabular}{|c|c|c|c|c|c|c|}
\hline \multirow{2}{*}{$\begin{array}{c}\text { Activated } \\
\text { temperature } \\
\left({ }^{\circ} \mathrm{C}\right)\end{array}$} & \multicolumn{3}{|c|}{ Yield (\%) } & \multicolumn{3}{|c|}{ Iodine value (mg/g) } \\
\hline & $\mathrm{CCAC}^{1)}$ & BPAC & MSAC & CCAC & $\mathrm{BPAC}$ & MSAC \\
\hline 700 & $26.6(0.5)^{2)}$ & $28.4(0.4)$ & $23.9(1.2)$ & $224(7)$ & $494(13)$ & $288(15)$ \\
\hline 750 & $25.6(1.8)$ & $27.8(0.3)$ & $22.4(0.9)$ & $402(8)$ & $939(13)$ & $378(9)$ \\
\hline 800 & $24.3(1.7)$ & $27.1(0.5)$ & $18.8(0.4)$ & $592(7)$ & 946 (16) & 685 ( 8$)$ \\
\hline 850 & $22.2(1.2)$ & $17.8(0.4)$ & $17.8(0.5)$ & $891(16)$ & $1020(23)$ & $347(7)$ \\
\hline 900 & $18.3(0.3)$ & $16.3(0.5)$ & $8.3(0.2)$ & 796 (14) & $943(18)$ & $250(8)$ \\
\hline 950 & $11.9(2.3)$ & $1.7(0.3)$ & $7.5(0.5)$ & 664 (18) & 871 (15) & $220(7)$ \\
\hline
\end{tabular}

1) CCAC: corn cob activated carbon; BPAC: bagasse pith activated carbon; MSAC: mushroom stalk activated carbon.

2) Values given are average values of three estimations and standard deviation. 
$800^{\circ} \mathrm{C}$. During this temperature period, it can be said that the pore-drilling effect and expansion effect are reached to the balance situation.

According to the aforesaid results of yield and iodine value of $\mathrm{AC}$, the corn cob $\mathrm{AC}$ at activation temperature of $850^{\circ} \mathrm{C}, 850^{\circ} \mathrm{C}$ bagasse pith $\mathrm{AC}$ and $800^{\circ} \mathrm{C}$ mushroom stalk AC were selected as the specimens for the following Ames test, cytotoxicity and mutagenicity.

\section{Ames test}

Cytotoxicity of $A C$

The cytotoxicity test results of the AC for the TA98 and TA100 strains are shown in Table 2. The residual bacteria rates of the AC with S9 and without S9 were higher than 80\%. Waleh et al. (1982) indicated that the number of residual bacteria of $S$. typhimurium must be over $80 \%$ of the control group to determine that the sample has no cytotoxicity for $S$. typhimurium. If the

Table 2. Cytotoxicity of corn cob, bagasse pith and mushroom stalk activated carbons toward S. typhimurium TA98, TA100 with or without S9 mixture

\begin{tabular}{|c|c|c|c|c|c|c|c|c|c|c|c|c|c|}
\hline \multirow[b]{2}{*}{ S9 } & \multirow{2}{*}{$\begin{array}{l}\text { Amount } \\
\text { (mg/ } \\
\text { plate) }\end{array}$} & \multicolumn{4}{|c|}{$\mathrm{CCAC}^{1)}$} & \multicolumn{4}{|c|}{ BPAC } & \multicolumn{4}{|c|}{ MSAC } \\
\hline & & TA98 & $\begin{array}{c}\text { Survival } \\
(\%)^{2)}\end{array}$ & TA100 & $\begin{array}{c}\text { Survival } \\
(\%)\end{array}$ & TA98 & $\begin{array}{c}\text { Survival } \\
\text { (\%) }\end{array}$ & TA100 & $\begin{array}{c}\text { Survival } \\
(\%)\end{array}$ & TA98 & $\begin{array}{c}\text { Survival } \\
(\%)\end{array}$ & TA100 & $\begin{array}{c}\text { Survival } \\
(\%)\end{array}$ \\
\hline \multirow{6}{*}{ Without } & 0.0 & $2413(31)^{3)}$ & 100 & $2346(75)$ & 100 & $2413(31)$ & 100 & $2346(75)$ & 100 & $2413(31)$ & 100 & $2346(75)$ & 100 \\
\hline & 1.0 & $2273(91)$ & 94 & 2517 ( 49) & 107 & 2482 ( 35$)$ & 103 & $2312(100)$ & 99 & 2401 ( 15$)$ & 100 & 2232 ( 24$)$ & 95 \\
\hline & 2.5 & 2339 ( 31$)$ & 97 & 2435 ( 57) & 104 & 2566 (59) & 106 & 2496 ( 87$)$ & 106 & 2331 ( 62) & 97 & 2343 (112) & 100 \\
\hline & 5.0 & 2683 ( 38$)$ & 111 & 2487 (103) & 106 & $2464(55)$ & 102 & 2618 (101) & 112 & $2607(40)$ & 108 & $2687(75)$ & 115 \\
\hline & 7.5 & $2628(23)$ & 109 & $2163(20)$ & 92 & $2422(60)$ & 100 & $2491(49)$ & 106 & 2830 (63) & 117 & 2407 (127) & 103 \\
\hline & 10.0 & $2890(66)$ & 120 & $2353(30)$ & 100 & $2511(50)$ & 104 & 2585 (95) & 110 & $2261(95)$ & 94 & 2435 (110) & 104 \\
\hline \multirow{6}{*}{ With } & 0.0 & $2547(119)$ & 100 & 2274 ( 37$)$ & 100 & $2547(119)$ & 100 & 2274 ( 37$)$ & 100 & 2547 (119) & 100 & 2274 ( 37$)$ & 100 \\
\hline & 1.0 & 2508 (114) & 98 & 2318 (187) & 102 & $2705(110)$ & 106 & 2138 (214) & 94 & $2510(93)$ & 99 & $2543(70)$ & 119 \\
\hline & 2.5 & 2567 (102) & 101 & 2739 (128) & 120 & $2704(169)$ & 106 & 2857 (179) & 126 & 2520 (187) & 99 & 2190 (158) & 96 \\
\hline & 5.0 & 2552 (103) & 100 & 2683 (100) & 118 & 2908 ( 90$)$ & 114 & $2715(67)$ & 119 & 2614 (112) & 103 & 2998 (179) & 132 \\
\hline & 7.5 & 2621 (196) & 103 & 2678 ( 17$)$ & 118 & $2896(56)$ & 114 & 2366 (109) & 104 & 2621 (130) & 103 & $2245(72)$ & 99 \\
\hline & 10.0 & 2635 (196) & 103 & 2435 (165) & 107 & 2875 (152) & 113 & 2531 (112) & 111 & 2479 (162) & 97 & $2584(122)$ & 114 \\
\hline
\end{tabular}

1) CCAC: corn cob activated carbon; BPAC: bagasse pith activated carbon; MSAC: mushroom stalk activated carbon.

${ }^{2)}$ Value in the residual bacteria rates (survival, \%) is the percentage relative to control (100\%).

3) Values given are average values of three estimations and standard deviation.

Table 3. Mutagenicity of corn cob, bagasse pith and mushroom stalk activated carbons toward S. typhimurium TA98, TA100 with or without S9 mixture

\begin{tabular}{cccccccccccccc}
\hline & $\begin{array}{c}\text { Amount } \\
\text { S9 }\end{array} \begin{array}{c}\text { (mg/ } \\
\text { plate) }\end{array}$ & TA98 & MR & TA100 & MR & TA98 & MR & TA100 & MR & TA98 & MR & TA100 & MR \\
\hline \multirow{6}{*}{ Without } & 2.5 & $40(2)$ & 1.25 & $200(5)$ & 0.88 & $25(2)$ & 1.04 & $190(6)$ & 0.89 & $30(2)$ & 0.93 & $211(2)$ & 1.06 \\
& 0.0 & $32(2)^{3)}$ & 1.00 & $228(6)$ & 1.00 & $24(2)$ & 1.00 & $214(5)$ & 1.00 & $32(2)$ & 1.00 & $200(4)$ & 1.00 \\
& 1.0 & $38(3)$ & 1.19 & $209(6)$ & 0.92 & $29(2)$ & 1.21 & $189(5)$ & 0.88 & $34(2)$ & 1.06 & $209(2)$ & 1.05 \\
& 5.0 & $37(3)$ & 1.16 & $193(4)$ & 0.85 & $28(2)$ & 1.17 & $182(2)$ & 0.85 & $37(2)$ & 1.16 & $186(3)$ & 0.93 \\
& 7.5 & $37(2)$ & 1.19 & $201(4)$ & 0.88 & $23(2)$ & 0.96 & $195(3)$ & 0.91 & $35(1)$ & 1.09 & $181(4)$ & 0.91 \\
& 10.0 & $36(2)$ & 1.13 & $215(7)$ & 0.94 & $24(2)$ & 1.00 & $209(4)$ & 0.98 & $37(2)$ & 1.16 & $222(5)$ & 1.11 \\
\hline \multirow{4}{*}{ With } & 0.0 & $22(1)$ & 1.00 & $149(2)$ & 1.00 & $22(1)$ & 1.00 & $148(3)$ & 1.00 & $25(1)$ & 1.00 & $156(4)$ & 1.00 \\
& 1.0 & $24(1)$ & 1.09 & $171(3)$ & 1.15 & $24(0)$ & 1.09 & $152(1)$ & 1.03 & $27(1)$ & 1.08 & $154(2)$ & 0.99 \\
& 2.5 & $22(1)$ & 1.00 & $166(1)$ & 1.11 & $25(1)$ & 1.14 & $145(3)$ & 0.98 & $24(2)$ & 0.96 & $157(4)$ & 1.01 \\
& 5.0 & $23(1)$ & 1.05 & $152(1)$ & 1.02 & $23(1)$ & 1.05 & $163(2)$ & 1.10 & $22(2)$ & 0.88 & $145(3)$ & 0.93 \\
& 7.5 & $24(2)$ & 1.09 & $150(2)$ & 1.01 & $24(1)$ & 1.09 & $144(1)$ & 0.97 & $27(2)$ & 1.08 & $145(2)$ & 0.93 \\
& 10.0 & $23(1)$ & 1.05 & $153(5)$ & 1.03 & $25(2)$ & 1.14 & $146(3)$ & 0.99 & $23(1)$ & 0.92 & $148(1)$ & 0.95 \\
\hline
\end{tabular}

\footnotetext{
${ }^{1)}$ CCAC: corn cob activated carbon; BPAC: bagasse pith activated carbon; MSAC: mushroom stalk activated carbon.

${ }^{2)} \mathrm{MR}$ (Mutagenicity ratio) = induced revertants per plate/spontaneous revertants per plate.

${ }^{3)}$ Values given are average values of three estimations and standard deviation.
} 
number of residual bacteria of test group is smaller than $80 \%$ of control group, the test material has a cytotoxicity effect on the strain. The results are shown in Table 2: the AC, with or without S9 metabolic activation in the concentration range (1-10 mg/plate), did not reduce the number of residual bacteria of TA98 and TA100. Therefore, the AC have no cytotoxicity for the test strains in the addition range of $1-10 \mathrm{mg} / \mathrm{plate}$, and the dose for mutagenicity test can be selected according to this range. Mutagenicity of $A C$

Table 3 shows the mutagenicity test results of corn cob AC, bagasse pith AC and mushroom stalk AC for TA98 and TA100. The corn cob AC, bagasse pith AC and mushroom stalk AC, with or without $\mathrm{S} 9$, in the test range (1-10 mg/plate), did not have exceeded spontaneous revertants by more than two times for $S$. typhimurium TA98 and TA100. In other words, the mutagenicity ratio (MR) is smaller than 2. According to the standard proposed by Ames et al. (1975), if the number of spontaneous revertants induced by the specimen is larger than the spontaneous revertants of control group by more than two times, the specimen has mutagenicity. Therefore, the AC have no mutagenicity for TA98 and TA100 strains, and they can be preliminarily regarded as safe and environmentally-friendly materials. However, in order to conform to the safe biomaterials specified in Category II of health food of the Ministry of Health and Welfare in Taiwan (1999), this study uses the corn cob AC prepared at activation temperature of $850^{\circ} \mathrm{C}$ as the specimen for in vivo test, to further assess biological safety.

\section{Biological safety assessment}

The preliminary test was carried out first in order to avoid unnecessary sacrifice of animals. The corn cob AC prepared at activation temperature of $850^{\circ} \mathrm{C}$ was fed at doses of $0.05,0.1,0.5,1.0$ and $5.0 \mathrm{~g} / \mathrm{kg}$; the clinical conditions, energy, body weight, food and water consumption of the tested animals were observed in a preliminary test. The results showed there was no adverse effect on the fed animals after 7 days, matching the result of the National Laboratory Animal Center (1993). The acute and subacute animal tests for animal body and the pathological observation on organs and tissues, urine test, blood analysis and blood serum biochemical analysis were carried out to evaluate the effects of corn cob AC pre- pared at activation temperature of $850^{\circ} \mathrm{C}$ on the in vivo organ functions, cell formation and metabolism of SD rat. Acute toxicity

The average weight, average food consumption and average drinking water consumption of the male and female SD rat fed with corn cob $\mathrm{AC}$ at $5 \mathrm{~g} / \mathrm{kg}$ during the beginning day to the $14^{\text {th }}$ day were similar to the results of control group $(0 \mathrm{~g} / \mathrm{kg})$. Therefore, the corn cob AC had no adverse effect on the body weight, food intake and water intake of SD rat of test group (results not shown in table). The effect of corn cob AC at $5 \mathrm{~g} / \mathrm{kg}$ on the feed conversion rate of SD rat is shown in Table 4. There was no obvious difference between the feed conversion rate of the test group of male SD rat on the $1^{\text {st }}$ and $7^{\text {th }}$ day and the male SD rat of the control group according to Duncan's analysis; and there was no obvious difference between the female SD rat of test group and the female SD rat of control group on the day of $1^{\text {st }}, 7^{\text {th }}$ and $14^{\text {th }}$. There was obvious difference between the male SD rat of test group and control group on the $14^{\text {th }}$, but there was no significant difference between female SD rat of test group and control group on the $14^{\text {th }}$ day; therefore, it is inferred that the corn cob AC had no effect on test groups of SD rat.

Subacute toxicity

According to the effects of different doses of corn cob AC on the body weight, feed consumption and drinking water consumption of SD rat (results not shown in table), there was no difference between control group and test group of male SD rat (1 and $0.5 \mathrm{~g} / \mathrm{kg} /$ day) in body weight, food intake and water intake on the $1^{\text {st }}$ to $28^{\text {th }}$ day, and there was no significant difference between the two groups and female rat fed with different doses of AC. The effect of feeding different doses of corn cob AC on the feed conversion rate of SD rat is shown in Table 5. There was no significant difference between the various groups of male $\mathrm{SD}$ rat on the $26^{\text {th }}$ day according to Duncan's analysis. There was a difference among female SD rat fed at $5.0,1.0$ and $0.5 \mathrm{~g} / \mathrm{kg}$ on the $26^{\text {th }}$ day, but there was no significant difference to the control group. Therefore, the feeding different doses of corn cob $\mathrm{AD}$ had no adverse effect on the feed conversion rate of SD rat.

\section{Observation of organs}

The effect of feeding different doses of corn cob AC

Table 4. Feeding corn cob activated carbon with $5 \mathrm{~g} \mathrm{~kg}^{-1}$ toward the average feed conversion rate of SD rat in acute toxicity test

\begin{tabular}{clccc}
\hline \multirow{2}{*}{ Sex } & Treatment & \multicolumn{3}{c}{ Average feed conversion rate ${ }^{1)}$} \\
\cline { 3 - 5 } & Blank & the $1^{\text {st }}$ day & the $7^{\text {th }}$ day & the $14^{\text {th }}$ day \\
\hline \multirow{2}{*}{ Male } & $0.37(0.20)^{\mathrm{a} 2)}$ & $0.40(0.04)^{\mathrm{a}}$ & $0.37(0.02)^{\mathrm{b}}$ \\
& $(5 \mathrm{~g} / \mathrm{kg})$ & $0.17(0.07)^{\mathrm{a}}$ & $0.38(0.40)^{\mathrm{a}}$ & $0.32(0.00)^{\mathrm{a}}$ \\
\multirow{3}{*}{ Female } & Blank & $0.17(0.14)^{\mathrm{a}}$ & $0.31(0.05)^{\mathrm{a}}$ & $0.25(0.04)^{\mathrm{a}}$ \\
& $(5 \mathrm{~g} / \mathrm{kg})$ & $0.56(0.20)^{\mathrm{a}}$ & $0.27(0.07)^{\mathrm{a}}$ & $0.28(0.05)^{\mathrm{a}}$ \\
\hline
\end{tabular}

\footnotetext{
${ }^{1)}$ Average feed conversion efficiency: (g weight gain) / (g feed consumed).

2) Average values (standard deviation) within a transverse with the different superscripts are significantly different $(\rho<0.05)$.
} 
Table 5. Feeding corn cob activated carbon in different doses toward the average feed conversion rate of SD rat in subacute toxicity test

\begin{tabular}{|c|c|c|c|c|c|}
\hline \multirow{2}{*}{ Sex } & \multirow{2}{*}{ Time } & \multicolumn{4}{|c|}{ Dose (g/kg/day) } \\
\hline & & 0 & 0.5 & 1.0 & 5.0 \\
\hline \multirow{5}{*}{ Male } & 3 & $0.36(0.12)^{\mathrm{a} 1)}$ & $0.25(0.04)^{\mathrm{a}}$ & $0.29(0.10)^{\mathrm{a}}$ & $0.32(0.08)^{\mathrm{a}}$ \\
\hline & 10 & $0.37(0.01)^{\mathrm{a}}$ & $0.35(0.02)^{\mathrm{a}}$ & $0.36(0.03)^{\mathrm{a}}$ & $0.36(0.02)^{\mathrm{a}}$ \\
\hline & 17 & $0.30(0.01)^{\mathrm{a}}$ & $0.32(0.03)^{\mathrm{a}}$ & $0.30(0.03)^{\mathrm{a}}$ & $0.29(0.01)^{\mathrm{a}}$ \\
\hline & 24 & $0.23(0.03)^{\mathrm{ab}}$ & $0.23(0.01)^{\mathrm{ab}}$ & $0.27(0.01)^{\mathrm{a}}$ & $0.21(0.04)^{\mathrm{bc}}$ \\
\hline & 26 & $0.30(0.03)^{\mathrm{a}}$ & $0.34(0.06)^{\mathrm{a}}$ & $0.24(0.06)^{\mathrm{a}}$ & $0.36(0.09)^{\mathrm{a}}$ \\
\hline \multirow{5}{*}{ Female } & 3 & $0.14(0.08)^{\mathrm{bc}}$ & $0.24(0.03)^{\mathrm{ab}}$ & $0.25(0.05)^{\mathrm{ab}}$ & $0.29(0.08)^{\mathrm{a}}$ \\
\hline & 10 & $0.28(0.02)^{\mathrm{a}}$ & $0.24(0.08)^{\mathrm{a}}$ & $0.25(0.04)^{\mathrm{a}}$ & $0.27(0.02)^{\mathrm{a}}$ \\
\hline & 17 & $0.23(0.04)^{\mathrm{ab}}$ & $0.20(0.03)^{\mathrm{bc}}$ & $0.24(0.04)^{\mathrm{ab}}$ & $0.27(0.00)^{\mathrm{a}}$ \\
\hline & 24 & $0.15(0.07)^{\mathrm{a}}$ & $0.18(0.03)^{\mathrm{a}}$ & $0.15(0.02)^{\mathrm{a}}$ & $0.17(0.02)^{\mathrm{a}}$ \\
\hline & 26 & $0.22(0.09)^{\mathrm{ab}}$ & $0.31(0.11)^{\mathrm{a}}$ & $0.37(0.13)^{\mathrm{a}}$ & $0.06(0.11)^{\mathrm{bc}}$ \\
\hline
\end{tabular}

${ }^{1)}$ Average values (standard deviation) within a transverse with the different superscripts are significantly different $(\rho<0.05)$.

Table 6. Feeding corn cob activated carbon in different doses toward the percentage of relative organ weight ${ }^{1)}$ of SD rat in subacute toxicity test

\begin{tabular}{|c|c|c|c|c|c|}
\hline \multirow{2}{*}{ Sex } & \multirow{2}{*}{ Organ } & \multicolumn{4}{|c|}{ Dose (g/kg/day) } \\
\hline & & 0 & 0.5 & 1.0 & 5.0 \\
\hline \multirow{6}{*}{ Male } & Heart & $0.30(0.02)^{\mathrm{b} 2)}$ & $0.30(0.03)^{\mathrm{b}}$ & $0.31(0.02)^{b}$ & $0.37(0.03)^{\mathrm{a}}$ \\
\hline & Liver & $2.92(0.15)^{\mathrm{b}}$ & $3.06(0.22)^{\mathrm{ab}}$ & $3.09(0.36)^{\mathrm{a}}$ & $2.86(0.16)^{b}$ \\
\hline & Spleen & $0.17(0.00)^{\mathrm{a}}$ & $0.19(0.03)^{\mathrm{a}}$ & $0.18(0.03)^{\mathrm{a}}$ & $0.20(0.04)^{\mathrm{a}}$ \\
\hline & Kidney & $0.74(0.03)^{\mathrm{a}}$ & $0.71(0.06)^{\mathrm{a}}$ & $0.75(0.07)^{\mathrm{a}}$ & $0.80(0.14)^{\mathrm{a}}$ \\
\hline & Testes & $0.76(0.12)^{\mathrm{a}}$ & $0.77(0.03)^{\mathrm{a}}$ & $0.77(0.04)^{\mathrm{a}}$ & $0.83(0.11)^{\mathrm{a}}$ \\
\hline & Heart & $0.33(0.03)^{\mathrm{a}}$ & $0.32(0.03)^{\mathrm{a}}$ & $0.33(0.01)^{\mathrm{a}}$ & $0.36(0.03)^{\mathrm{a}}$ \\
\hline \multirow{4}{*}{ Female } & Liver & $3.05(0.52)^{\mathrm{a}}$ & $2.98(0.28)^{\mathrm{a}}$ & $2.97(0.14)^{\mathrm{a}}$ & $2.92(0.33)^{\mathrm{a}}$ \\
\hline & Spleen & $0.20(0.06)^{\mathrm{a}}$ & $0.19(0.03)^{\mathrm{a}}$ & $0.18(0.03)^{\mathrm{a}}$ & $0.21(0.02)^{\mathrm{a}}$ \\
\hline & Kidney & $0.75(0.11)^{\mathrm{a}}$ & $0.76(0.04)^{\mathrm{a}}$ & $0.71(0.07)^{\mathrm{a}}$ & $0.76(0.06)^{\mathrm{a}}$ \\
\hline & Ovary & $0.04(0.02)^{\mathrm{b}}$ & $0.05(0.01)^{\mathrm{ab}}$ & $0.06(0.02)^{\mathrm{ab}}$ & $0.08(0.03)^{\mathrm{a}}$ \\
\hline
\end{tabular}

\footnotetext{
1) The percents (\%) of relative weights of rat's organ equal to weights of organ divided by body weights then multiplied 100 .

${ }^{2)}$ Average values (standard deviation) within a transverse with the different superscripts are significantly different $(\rho<0.05)$.
}

in the subacute test on the relative weight percentage of organs of SD rat is shown in Table 6. There was no significant difference between the test groups and control groups of SD rat according to Duncan's analysis. The weight percentages of organs of various groups were described as follows: the weight percentage of Heart of male SD rat (0-5.0 g/kg) was $0.30-0.37 \%$; that of Liver was $2.86-3.09 \%$; that of Spleen was $0.17-0.20 \%$; that of Kidney was $0.71-0.80 \%$; that of Testes was $0.76-0.83 \%$. The weight percentage of Heart of female SD rat $(0-5.0 \mathrm{~g} / \mathrm{kg})$ was $0.32-0.36 \%$; that of Liver was $2.92-$ $3.05 \%$; that of Spleen was $0.18-0.21 \%$; that of Kidney was $0.71-0.76 \%$; that of Ovary was $0.04-0.08 \%$. According to the aforesaid results of male SD rat and female SD rat, the weights and percentages of various organs of SD rat were similar. Therefore, the dose of $0.5-5.0 \mathrm{~g} / \mathrm{kg}$ had no toxicity in regard to the rat's organs.
The pathologic tissue slice items of the maximum dose level group $(5 \mathrm{~g} / \mathrm{kg})$ and control group of male SD rat included heart, liver, kidney, spleen, duodenum, and testes (male) / ovary (female) results (Fig. 1). The myocardial cells of test and control groups of SD rat had no rupture, and the central karyon and RBC were not broken (Fig. 1. A, ×400). The pattern was similar to the normal cardiac atlas of Histology and Cytobiology written by Abraham and Laura (2006). The hepatocytes at the liver and gall triad were not injured, and the blood cells in the vein were complete without hemolysis (Fig. 1. B, ×400) and there were no fat and inflammatory reactions in the liver. The glomeruli showed that the podocytes and mesangial cells were complete without injury. It is indicated that the $\mathrm{AC}$ does not cause pathological change in the kidney (Fig. 1. C, ×400). The splenic red pulp and white pulp were similar to the control group, and there 
was no leukocytosis (Fig. 1. D, ×400). There was no adverse effect on the spleen of the test group fed with corn cob AC. Abraham and Laura (2006) indicated that the red pulp in the spleen was blood filter, and it was able to remove old and disabled RBCs and microorganisms from circulating blood, and it stores blood cells. The white pulp was for immunoreaction. This part contains the central artery, periarteriolar lymphoid sheaths, gen-

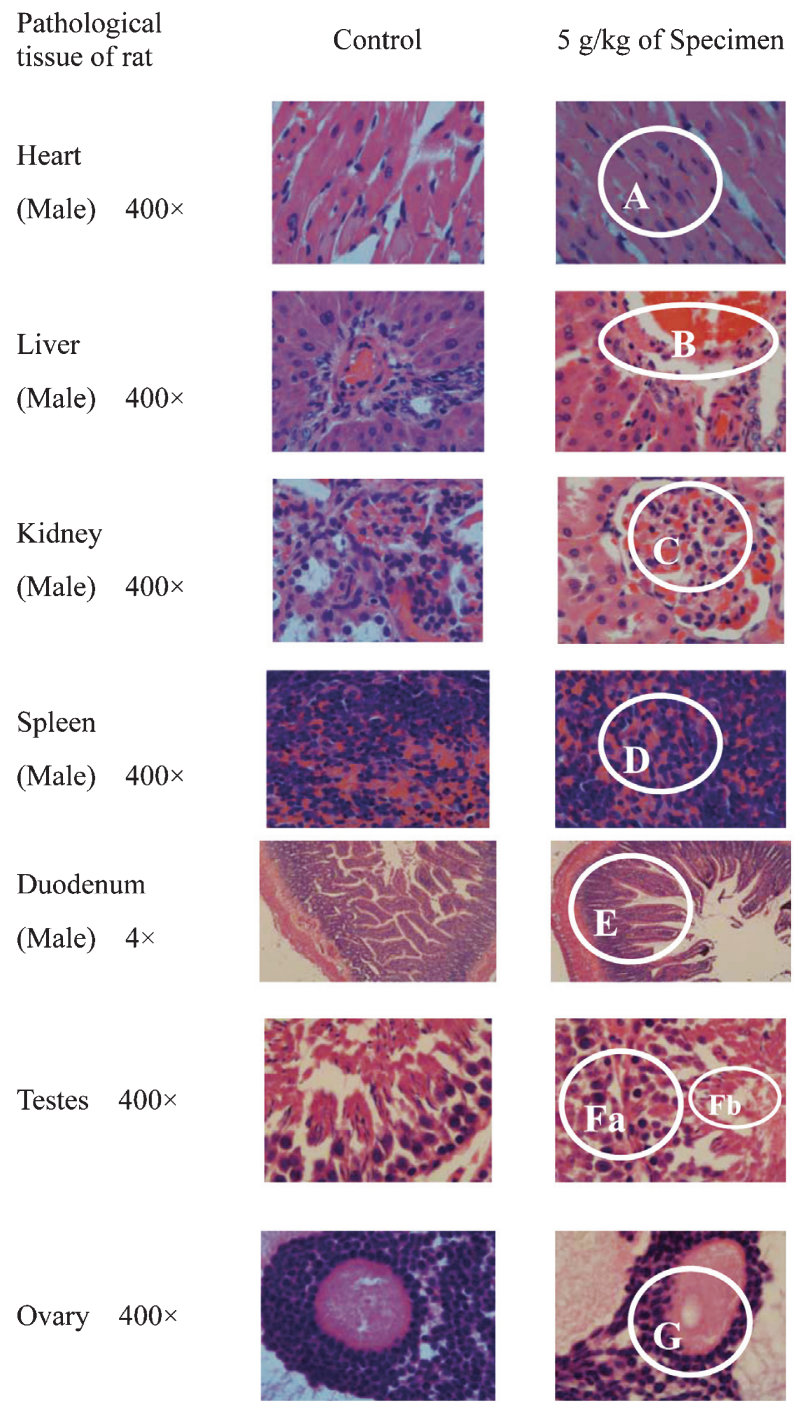

Fig. 1. Observations on pathological tissue of rat by daily gavages for $850^{\circ} \mathrm{C}$ corn cob activated carbon in the subacute toxicity tests. eration center and coronal area formed of antigen presenting cells of B-cell; the red pulp was an interconnected reticular sinus lienis. The spleen beam contains plasma cell, macrophage and corpuscle which were supported by reticulocyte and reticular fiber in substrate. There was no exfoliation at the finger-like villi of duodenum, and the muscle was complete (Fig. 1. E, ×4). In addition, the nucleoli of early spermatid (Fig. 1. Fa, $\times 400$ ), spermatocyte, spermospore and late spermatid (Fig. 1. Fb, ×400)were complete, and the late spermatid flagella were not ruptured. In terms of the ovarian mature follicle of female SD rat (Fig. 1. G, $\times 400$ ), the tissue observation results of test group and control group were similar. According to the aforesaid results, feeding AC had no adverse effect on the organ functions of SD rat. Urinalysis

The urinalysis of SD rat fed with different doses of corn cob AC is shown in Table 7. The urine color of test group and control group was yellow; the specific gravity was 1 ; the O.B, glucose and bilirubin of test group and control group presented negative reactions. The urine $\mathrm{pH}$ of the test and control groups was 6.5-8.0. The test group of male SD rat at 1.0 and $5.0 \mathrm{~g} / \mathrm{kg}$ had a little amount of ketones; the control group and others of SD rat had a little albuminuria. The ketones were not a normal urine constituent; it represented defects in the carbohydrate metabolism; the ketonuria was caused by diabetes (Shen, 2002). The SD rat of test group at dose of 1.0 and $5.0 \mathrm{~g} / \mathrm{kg}$ presented slight reaction $( \pm)$, although there was no positive reaction, as there was no glucose; it was inferred that feeding $\mathrm{AC}$ did not cause urine ketones of SD rat. The test and control groups presented urinary protein. According to Table 7, the control group of male SD rat and $1.0 \mathrm{~g} / \mathrm{kg}$ test group present slight reaction $( \pm$ ) (the same as female; not shown in table); there was no true positive and negative significance. The test group of male SD rat at 0.5 and $5.0 \mathrm{~g} / \mathrm{kg}$ presented $\mathrm{a}+$, a + value was $0.3 \mathrm{mg} / \mathrm{mL}$. It is in normal range, like the result of the National Laboratory Animal Center (1993). Blood analysis

The blood analysis results of male SD rat fed with different doses of corn cob AC are shown in Table 8. There was no difference between the values of test groups of SD rat with different feeding doses and control groups. The WBC count of male SD rat was 8517-10033/uL, RBC count was 720-737 104/uL, HGB was 15-16 g/dL, HCT

Table 7. Feeding corn cob activated carbon in different doses toward the urinalysis of SD male rat in subacute toxicity test

\begin{tabular}{|c|c|c|c|c|c|c|c|c|c|}
\hline $\begin{array}{c}\text { Dose } \\
\text { (g/kg/day) }\end{array}$ & Urine Color & Sp.Gr. ${ }^{1)}$ & $\mathrm{pH}^{2)}$ & $\begin{array}{c}\text { O.B }{ }^{3)} \\
(\mathrm{mg} / \mathrm{dL})\end{array}$ & $\begin{array}{l}\text { Nitrite } \\
(\mathrm{mg} / \mathrm{dL})\end{array}$ & $\begin{array}{l}\text { Ketones } \\
\text { (mg/dL) }\end{array}$ & $\begin{array}{c}\text { Glucose } \\
(\mathrm{g} / \mathrm{dL})\end{array}$ & $\begin{array}{l}\text { Protein } \\
(\mathrm{mg} / \mathrm{dL})\end{array}$ & $\begin{array}{l}\text { Bilirubin } \\
\text { (mg/dL) }\end{array}$ \\
\hline 0.0 & $\mathrm{Y}^{4)}$ & $1.0(0.0)^{5)}$ & $7.5(0.0)$ & - & - & $-{ }^{6)}$ & - & \pm & - \\
\hline 0.5 & $\mathrm{Y}$ & $1.0(0.0)$ & $8.0(0.0)$ & - & - & - & - & $+{ }^{7)}$ & - \\
\hline 1.0 & $\mathrm{Y}$ & $1.0(0.0)$ & $6.5(0.0)$ & - & - & \pm & - & \pm & - \\
\hline 5.0 & $\mathrm{Y}$ & $1.0(0.0)$ & $7.8(0.0)$ & - & - & \pm & - & + & - \\
\hline
\end{tabular}

${ }^{1)}$ Sp.Gr.: specific gravity; ${ }^{2)} \mathrm{pH}$ : hydragen ion concentration; ${ }^{3)}$ O.B: occult blood; ${ }^{4)}$ Y: yellow color; ${ }^{\text {5) }}$ Value (standard deviation);

${ }^{6)}$ negative: $-{ }^{7}$ positive: + 
was 46-48\%, mean corpuscular volume (MCV) was 64-65 $\mathrm{fL}$, mean corpuscular hemoglobin (MCH) is 20-22 pg, mean corpuscular hemoglobin concentration (MCHC) was 31-34 g/dL, platelet (PLT) is 95-98 $104 \mathrm{uL}^{-1}$ and Lymphocyte percent (Lymph) was 85-90\% (female has the same trend; not shown in table). According to the hematological normal values of SD rat indicated by the National Laboratory Animal Breeding and Research Center (1993), WBC count is $6000-13000 / \mathrm{uL}, \mathrm{RBC}$ count is $700-1000104 / \mathrm{uL}, \mathrm{HGB}$ is $11-17 \mathrm{~g} / \mathrm{dL}$, HCT is $35-53 \%$, MCV is $53-73 \mathrm{fL}, \mathrm{MCH}$ is $5-10 \mathrm{pg}, \mathrm{MCHC}$ is $29-34 \mathrm{~g} / \mathrm{dL}$, PLT is 50-130 104/uL and Lymph is 65-85\%. Compared

Table 8. Feeding corn cob activated carbon in different doses toward the blood analysis of SD male rat in subacute toxicity test

\begin{tabular}{|c|c|c|c|c|}
\hline \multirow{2}{*}{ Items $^{1)}$} & \multicolumn{4}{|c|}{ Dose (g/kg/day) } \\
\hline & 0.0 & 0.5 & 1.0 & 5.0 \\
\hline WBC $(\mu \mathrm{L})$ & $10033(5129)^{\mathrm{a} 2)}$ & $9600(1837)^{\mathrm{a}}$ & $8517(2895)^{\mathrm{a}}$ & $11250(4084)^{\mathrm{a}}$ \\
\hline $\operatorname{RBC}\left(10^{4} / \mu^{\mathrm{L}}\right)$ & $728(14)^{\mathrm{a}}$ & $737(28)^{a}$ & $720(30)^{\mathrm{a}}$ & $735(54)^{\mathrm{a}}$ \\
\hline HGB (g/dL) & $16(1)^{\mathrm{a}}$ & $16(0)^{\mathrm{a}}$ & $15(3)^{\mathrm{a}}$ & $16(1)^{\mathrm{a}}$ \\
\hline $\mathrm{HCT}(\%)$ & $46(3)^{\mathrm{a}}$ & $48(2)^{\mathrm{a}}$ & $47(2)^{\mathrm{a}}$ & $48(4)^{\mathrm{a}}$ \\
\hline MCV (fL) & $64(3)^{\mathrm{a}}$ & $65(1)^{\mathrm{a}}$ & $65(4)^{\mathrm{a}}$ & $65(2)^{\mathrm{a}}$ \\
\hline MCH (pg) & $22(1)^{\mathrm{a}}$ & $22(0)^{\mathrm{a}}$ & $20(3)^{\mathrm{a}}$ & $22(1)^{\mathrm{a}}$ \\
\hline $\mathrm{MCHC}(\mathrm{g} / \mathrm{dL})$ & $34(1)^{\mathrm{a}}$ & $34(0)^{\mathrm{a}}$ & $31(6)^{\mathrm{a}}$ & $34(1)^{\mathrm{a}}$ \\
\hline $\operatorname{PLT}\left(10^{4} / \mu^{\mathrm{L}}\right)$ & $98(11)^{a}$ & $95(9)^{\mathrm{a}}$ & $95(14)^{\mathrm{a}}$ & $95(1)^{\mathrm{a}}$ \\
\hline Lymph (\%) & $89(2)^{a}$ & $90(2)^{a}$ & $85(3)^{a}$ & $88(3)^{a}$ \\
\hline \multicolumn{5}{|c|}{$\begin{array}{l}{ }^{1)} \text { WBC count: white blood cell count; RBC count: red blood cell count; HGB: hemoglobin; HCT: hematocrit; } \\
\text { MCV: mean corpuscular volume; MCH: mean corpuscular hemoglobin; MCHC: mean corpuscular } \\
\text { hemoglobin concentration; PLT: platelet; Lymph: lymphocyte percent. }\end{array}$} \\
\hline
\end{tabular}

Table 9. Feeding corn cob activated carbon in different doses toward blood serum biochemical analysis of SD male rat in subacute toxicity test

\begin{tabular}{|c|c|c|c|c|}
\hline \multirow{2}{*}{ Items $^{1)}$} & \multicolumn{4}{|c|}{ Dose (g/kg/day) } \\
\hline & 0.0 & 0.5 & 1.0 & 5.0 \\
\hline $\operatorname{ALB}(\mathrm{g} / \mathrm{dL})$ & $5(0)^{\mathrm{a} 2)}$ & $5(0)^{\mathrm{a}}$ & $4(0)^{\mathrm{a}}$ & $4(0)^{\mathrm{a}}$ \\
\hline $\operatorname{ALP}(\mathrm{u} / \mathrm{L})$ & $456(27)^{\mathrm{a}}$ & $429(100)^{\mathrm{a}}$ & $389(75)^{\mathrm{a}}$ & $447(105)^{\mathrm{a}}$ \\
\hline $\mathrm{ALT}(\mathrm{u} / \mathrm{L})$ & $44(2)^{a}$ & $43(3)^{\mathrm{a}}$ & $46(7)^{\mathrm{a}}$ & $48(8)^{a}$ \\
\hline $\operatorname{AST}(\mathrm{u} / \mathrm{L})$ & $151(25)^{\mathrm{a}}$ & $161(40)^{\mathrm{a}}$ & $162(53)^{\mathrm{a}}$ & $152(17)^{\mathrm{a}}$ \\
\hline BUN (mg/dL) & $27(1)^{\mathrm{a}}$ & $28(2)^{\mathrm{a}}$ & $27(3)^{\mathrm{a}}$ & $28(2)^{\mathrm{a}}$ \\
\hline CRE (mg/dL) & $1(0)^{\mathrm{a}}$ & $1(1)^{\mathrm{a}}$ & $1(0)^{\mathrm{a}}$ & $1(0)^{\mathrm{a}}$ \\
\hline$\gamma-\mathrm{GTP}(\mathrm{u} / \mathrm{L})$ & $0(0)^{\mathrm{a}}$ & $0(0)^{\mathrm{a}}$ & $0(0)^{\mathrm{a}}$ & $0(0)^{\mathrm{a}}$ \\
\hline GLO (mg/dL) & $2(0)^{\mathrm{a}}$ & $2(0)^{a}$ & $2(0)^{\mathrm{a}}$ & $2(0)^{\mathrm{a}}$ \\
\hline GLU (mg/dL) & $105(4)^{\mathrm{a}}$ & $120(65)^{\mathrm{a}}$ & $98(46)^{\mathrm{a}}$ & $106(23)^{\mathrm{a}}$ \\
\hline $\mathrm{T}-\mathrm{PRO}(\mathrm{mg} / \mathrm{dL})$ & $7(0)^{\mathrm{a}}$ & $7(0)^{\mathrm{a}}$ & $7(0)^{a}$ & $7(0)^{\mathrm{a}}$ \\
\hline $\mathrm{A} / \mathrm{G}$ & $2(0)^{a}$ & $2(0)^{\mathrm{a}}$ & $2(0)^{\mathrm{a}}$ & $2(0)^{\mathrm{a}}$ \\
\hline $\mathrm{Na}(\mathrm{mmol} / \mathrm{L})$ & $148(2)^{\mathrm{a}}$ & $149(1)^{\mathrm{a}}$ & $149(1)^{\mathrm{a}}$ & $149(1)^{\mathrm{a}}$ \\
\hline $\mathrm{K}(\mathrm{mmol} / \mathrm{L})$ & $6(1)^{\mathrm{a}}$ & $7(1)^{\mathrm{a}}$ & $8(2)^{a}$ & $8(1)^{a}$ \\
\hline $\mathrm{Cl}$ (mmol/L) & $99(2)^{a}$ & $99(2)^{\mathrm{a}}$ & $99(3)^{\mathrm{a}}$ & $98(2)^{\mathrm{a}}$ \\
\hline $\mathrm{Ca}(\mathrm{mg} / \mathrm{dL})$ & $11(0)^{\mathrm{a}}$ & $10(1)^{\mathrm{a}}$ & $9(4)^{\mathrm{a}}$ & $9(2)^{\mathrm{a}}$ \\
\hline $\mathrm{P}$ (mg/dL) & $22(1)^{a}$ & $22(1) \mathrm{a}$ & $22(3) a$ & $24(2)^{\mathrm{a}}$ \\
\hline
\end{tabular}

1) ALB: albumin; ALP: alkaline phosphatase; ALT: alanine aminotransferase; AST: aspartate aminotransferase; BUN: blood urea nitrogen; CRE: creatinine; $\gamma$-GTP: $\gamma$-glutamyltransferase; GLO: globulin; GLU: glucose; T-PRO: total protein; A/G: albumin/globulin ratio; Na: sodium; K: potassium; Cl: chloride; Ca: calcium; P: phosphorus.

${ }^{2)}$ Average values (standard deviation) within a transverse with the different superscripts are significantly different $(\rho<0.05)$. 
with the values specified by the National Laboratory Animal Center, only the MCH of test groups and control groups of SD rat was higher than the latter one. However, Tsang's Veterinary Hematology of Chau-Loong Tsang indicates that the MCH vary with MCHC (Tsang, 1994), and its clinical interpretation is less meaningful than MCV and MCHC. There was no significant difference between the test groups and control groups in $\mathrm{MCH}$. It is inferred that feeding different doses of AC has no effect on the bone marrow function of tested animals. Blood serum biochemical analysis

The biochemical effect of different doses of corn cob AC on the blood serum of male SD rat is shown in Table 9. The results of various groups showed no significant difference in statistical analysis (the same as results of female SD rat; not shown in table). According to the blood serum biochemical reference data of SD rat of the National Laboratory Animal Breeding and Research Center (1993) and previous studies (Shen, 2006; Tsai et al., 2005): albumin (ALB): 3.8-4.8 g/dL; alkaline phosphatase (ALP): 66-200 u/L; ALT: 21-26 u/L; AST: 90-130 u/L; blood urea nitrogen (BUN): $15-21 \mathrm{mg} / \mathrm{dL}$; creatinine (CRE): 0.3-0.6 mg/dL; $\gamma$-glutamyltransferase ( $\gamma$-GTP): $40 \mathrm{u} / \mathrm{L}$; globulin (GLO): 1.8-3.0 mg/dL; glucose (GLU): 50-135 mg/dL; total protein (T-PRO): 7.1-7.9 mg/ dL; Albumin/globulin ratio (A/G): 1.6-2.1; sodium (Na): 137-143 mmol/L; potassium (K): 5.7-5.9 mmol/L; chloride $(\mathrm{Cl})$ : $100-103 \mathrm{mmol} / \mathrm{L}$; calcium (Ca): 10.3-12.2 mg/ $\mathrm{dL}$; phosphorus (P): 6.5-9.2 mg/dL. Compared with the aforesaid literatures, the ALP, ALT, AST and BUN of the control group and test groups of SD rats were in the range of the National Laboratory Animal Center (1993). The increase in the ALP resulted from the animal age (younger has higher value in usual) or hepatic disease (Jian, 1983). The ALT and AST are important indexes of hepatic necrosis examination; heart disease, injury and tumor shall be identified before examination (Shen, 2002). The BUN is higher than the standard resulted from nephritis, urinary tract obstruction, and congestive cardiac failure. It is one of the indicators for judging kidney function as CRE and blood electrolyte (Jian, 1983). The AST and ALT were too high in different experimental animals, but there was no significant difference compared with the control group. Therefore, if it resulted from feeding $\mathrm{AC}$, the control group was in the range of the literatures, so it did not result from feeding AC. The BUN and $\mathrm{P}$ in various tests were higher than the results of the National Laboratory Animal Center (1993), but there was no significant difference, and the control group also had this phenomenon in tests. Therefore, it was not caused by AC directly.

\section{CONCLUSION}

The yield range of the three agricultural wastes as the precursors to prepare AC was 1.7-28.4\%. The bagasse pith AC had the best iodine value, about $1020 \mathrm{mg} / \mathrm{g}$. According to the results of yield and iodine value, the corn cob AC at activation temperature of $850^{\circ} \mathrm{C}, 850^{\circ} \mathrm{C}$ bagasse pith $\mathrm{AC}$ and $800^{\circ} \mathrm{C}$ mushroom stalk $\mathrm{AC}$ were used as the specimens for the cytotoxicity and mutagenicity tests. As for the performance of the AC, the number of residual bacteria was higher than $80 \%$ of the control group, meaning there was no cytotoxicity. The AC did not have exceeded spontaneous revertants by more than two times for S. typhimurium TA98 and TA100, so the $\mathrm{AC}$ had no mutagenicity. The specimen for the in vivo test was corn cob AC at activation temperature of $850^{\circ} \mathrm{C}$. According to the acute toxicity and subacute results, none of experimental animals died in the breeding period; the LD50 was higher than $5.0 \mathrm{~g} / \mathrm{kg}$. The feed consumption of control group and test group in the test period was less than that recorded in the animal breeding manual of the National Laboratory Animal Breeding and Research Center, but the feed consumption of control group also decreased. It is indicated that the decrease in food consumption does not result from feeding AC. In urine, blood and serum analyses, there was no significant difference between the control group and test group in organ weight and organ weight percentage according to Duncan's ANOVA. In terms of tissue pathology observation, there was no organopathy or inflammation in maximum dose level group. The aforesaid results showed that the tested specimens had no systematic poison for experimental animals, and the atoxic dose was higher than $5.0 \mathrm{~g} / \mathrm{kg}$. According to the test concentration of $5.0 \mathrm{~g} / \mathrm{kg}$ of corn cob AC (average adult body weight is $70 \mathrm{~kg}, 350 \mathrm{~g}$ each time per day) and ADI (Acceptable Daily Intake), the daily adult (average weight $70 \mathrm{~kg}$ ) intake is $3.5 \mathrm{~g}$, this is safe within the ADI range. This result is the safe dose of commercially functional $\mathrm{AC}$, and it can increase the added value of agricultural wastes in application.

\section{ACKNOWLEDGEMENTS}

The authors offer the sincere appreciation to the National Science Council through Grant No. NSC 95-2313-B-415-014 for financial support.

\section{REFERENCES}

Abe, I., M. Hitomi, N. Ikuta, I. Kawafune and Y. Kera 1961 Properties of porous carbons prepared from the wood of Japanese Cypress - Effect of carbonization time at $900^{\circ} \mathrm{C}$. Carbon, 34(11): 1455-1455

Abraham, L. K. and L. T. Laura 2006 Histology and Cell Biology An Introduction to Pathology, $3^{\text {rd }}$ edition. Amazon pp. 25-500

Ames, B. N., J. McCann and E. Yamasaki 1975 Methods for detecting carcinogens and mutagens with the Salmonella/mammalian - Microsome mutagenicity test. Mutat Res., 31: 347-364.

Chang, C. F., C. Y. Chang, S. L Chang, S. Y. Lee and P. C. Wang 1998 Effect of physical carbonization and activation methods on the preparation of activated carbon corn cob. J. Chinese Institute of Envi. Eng., 8: 227-232

Chang, C. F., C. Y. Chang, J. L. Shie, S. L. Lee, S. Y. Wang, P. S. Lin and W. T. Tsai 2003 Production of activated carbons from agricultural waste corn cob by chemical and/or physical activations: An overview. J. Chinese Institute of Envi. Eng., 13(2): $135-141$

Chen, H. B. 2003 Manufacturing of Bamboo Charcoal and Activated Carbon. Department of Wood Science and design. National Pingtung University of Science and Techology, Master thesis

Chou, C. Y. 1988 Development of Agricultural Wastes Process. 
Extended abstracts, 1998 Memorial Symposium on Kou CM, Taiwan ROC, National Taiwan University pp. 121-130

Council of Agriculture 2011 The Council of Agriculture (COA) Annual Report. COA, Executive Yuan, Taiwan ROC

Hsieh, C. T. 1998 Influence of Pore Structures and Preparation Process of Activated Carbon on Liquid-phase Adsorption. Department of chemical engineering, Chung Yuan Christian University, Master thesis

Hsieh, C. T. and H. Teng 1999 Effect of adsorption capacity for mesopore activated carbon in liquid phase. J Chem Eng., 46 (6): $92-100$

Hsia, H. Z. 1972 Nutrition of Bagasse. San Min Book Co Ltd pp. $45-81$

Huang, L. T. 2002 Preparation and Application of High Surface Area Carbons from Rice and Peanut Hull. Department of Chemical Engineering, National Taiwan University of wScience and Techology, Master thesis

Huang, W. J., M. H. Duh and H. C. Lin 2010 Investigation os Absorption Properties of Activated Carbon Fibers Prepared from Nadelholz/Laubholz Pulp. J. Agric. For., 7(1): 16-31

Jian, Q. Y. 1983 Illustration of Small Animal Disease. HSY Co, Taiwan ROC pp. 7-22

Juang, R. S., F. C. Wu and R. L. Tseng 2000 Mechanism of adsorption of dyes and phenols from water using activated carbons prepared from plum kernels. J. Colloid Interface Sci., 227: $437-444$

Lu, F. S. 1993 Special Topic of Dryland Crops. Legal Foundation for Development Fund of Dryland Crops, Taiwan pp. 173-319

Lu, G. Q. 1994 Evolution of pore structure of high-ash char during activation. Fuel, 145: 73

Lua, A. C. and J. Guo 2000 Activated carbon prepared from oil palm stone by one-step $\mathrm{CO}_{2}$ activation for gaseous pollutant removal. Carbon, 38: 1089-1097

Maron, D. M. and B. N. Ames 1983 Revised methods for the Salmonella mutagenicity Test. Mutat Res., 113: 173-215

Ministry of Health and Welfare 1998 The Good Laboratory Practice for Nonclinical Laboratory Studies. Ministry of Health and Welfare, Executive Yuan, Taiwan ROC

Ministry of Health and Welfare 1999 The Health Food Safety Assessment Method. Ministry of Health and Welfare, Executive Yuan, Taiwan ROC

National Laboratory Animal Center 1993 Report of National Laboratory Animal Breeding and Research. National Laboratory Animal Center (NLAC) Taiwan ROC

Peng, C. W., Y. N. Wang, T. C. Shiah, M. J. Chung and H. C. Lin 2010 Investigation on White Popinac (Leucaena leucocephala) Ash as a Natural Activating Agent for Activated Carbon Preparation. J. Exp. For. Nat. Taiwan Univ., 24(4): 247-260

Shen, Y. S. 2002 Diagnostics of Veterinarian Experiment. HSY Co, Taiwan pp. 250-278

Shen, H. R. 2006 Safety Eevaluation and Antioxidant Properties of Agaricus Blazei Murrill. Department of Food Science, National Chiayi University, Master thesis

Teng, H. and L. Y. Hsu 1999 Hing-porosity carbons prepared from bituminous coal with potassium hydroxide activation. Eng
Chem Res., 38: 2947

The Emergency Response Information Center Environmental Protection Administration 2006 The Prevention and Response Manual. The Emergency Response Information Center Environmental Protection Administration (EPA), Executive Yuan, Taiwan ROC

The Emergency Response Information Center Environmental Protection Administration 2006 Environmental Protection Administration (EPA) Report of Resource Recovery Fourin-One Program and Full Waste Classification and Zero Waste Group Action Plan. EPA, Executive Yuan, Taiwan $\mathrm{ROC}$

Tsai, M. C., J. W. Liao, S. H. Tseng C. H. Chuan, S. S. Wu and S. Yang 2005 Safety evaluation of processed agricultural foods. Plant Prot Bull., 47: 403-418 (2005).

Tsang, C. L. 1994 Tsang's Veterinary Hematology. Yi Hsien Publishing Co Ltd, Taiwan ROC pp. 67-245

Tseng, L. Y., S. C. Wu and H. C. Lin 2007 Mutagenic evaluation and physical absorption properties of corn cob, bagasse pith and mushroom stalk activated carbon. J Agric. For., $\mathbf{4}(2)$ $1-17$

Tung, T. C., P. C. Huang, H. C. Lee and S. L. Chen 1961 Nutrition ingredients of food in Taiwan. J Taiwanese Medical Science, 60(11): 973-1005.

Waleh, N. S., S. J. Rapport and K. E. Mortelmans 1982 Development of a toxicity test to be coupled to the Ames Salmonella assay and the method of construction of the required strains. Mutat Res., 97: 247-256

Walker, P. L. and J. A. Almagro 1995 Activation of pre-chlorinated anthracite in carbon dioxide and steam. Carbon, 33: 239 (1995)

Wang, S. Y. and S. I. Ting 1984 Forestry Products. The Commercial Press Ltd. pp. 430-432

Wigmans, T. 1989 Industrial aspects of production and use of activated carbons. Carbon, 27: 13

Wu, F. C. and R. L. Tseng 2000 Adsorption characteristics and pore structure of activated carbons prepared from agricultural wastes. Taiwanese $J$ of Agricultural Chemistry and Food Science, 38(3): 205-213

Wu, F. T. and Z. R. Tseng 1999 Study on Activated Carbon preparation of Wood Based Wastes. Technology, 14(4): 533-540

Wu, W. L., S. C. Wu and H. C. Lin 2010 Investigation on Water Activity and Absorption Properties of Activated Carbons Prepared from Agricultural Wastes Using Methods of Physical Activation with $\mathrm{CO}_{2}$ and Steam. J. Agric. For., 7(1): 1-15

Yang, S. C. 1992 Reuse and process of agricultural wastes. Tainan district agricultural research and extension station, COA, Executive Yuan, Taiwan ROC

Yang, C. C., C. F. Lin and S. K. Wang 2003 Re-utilization and process of Wastes in Taiwan. National Open University, Taipei pp. 7-32

Yasubu, Y. T. 1996 Utilization an d preparation of charcoal absorption. Wood Industry, 51(7): 294-300

Yun, C. H., Y. H. Park and C. R. Park 2001 Effects of Precarbonization on Porosity Development of Activated Carbons from Rice Straw. Carbon, 39: 559-567 